\section{Editorial Pointers}

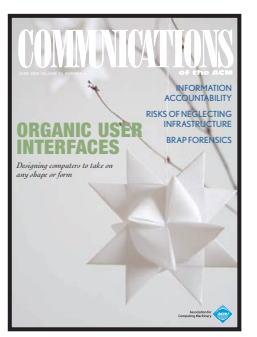

WiTH THIS ISSUE, WE CLOSE ONE CHAPTER IN THE evolving history of Communications and prepare to write another. Indeed, it is only fitting that a publication dedicated to chronicling how science and technology change our world take a look within to assess how best to recharge the editorial direction driven by those changes.

The editorial mix in this issue certainly befits the Communications legacy. We begin with a stunning collection of stories and images that tell of a (near) future where computing takes any shape or form - displays that bend and fold, that start as one shape but change with user needs_courtesy of the emerging field of Organic User Interfaces. There is also a pronouncement from a stellar group of Web industry leaders who argue that personal accountability must be a strong component of great technological work. And interspersed throughout the issue are accounts of real-world applications and practices that serve to teach, explore, and spark discussion.

The July issue will unveil a new editorial model and striking new look. Editor-in-chief Moshe Vardi gave us an early peek at this model in the January 2008 issue (http://mags.acm.org/communications/200801/). Former ACM President David Patterson explains the process and factors that inspired the redesign in a Webcast available at http://www.acm.org/news/featured/cacm-redesign/. And if you are interested in exploring editorial opportunities, please see the new Author Guidelines on page 105.

Words will never convey the gratitude and appreciation for all who have served Communications and its readers for the past 15 years. The next editorial vision finds roots in the tireless efforts of our Editorial Advisory Board, as well as the authors, columnists, and reviewers always striving to maintain the editorial quality Communications readers demand. And words can never capture how this editorial staff continues to produce top-quality issues each month, besting comparable publications with four times the headcount.

To Art Director Caren Rosenblatt, who leaves us with this issue, words are no match for her deft talent in welcoming a reader into a story with elegant imagery. This issue clearly reflects the graphic gift she brought to the table every month for 12 years. It is a testament to her ability that under her guidance, a dozen illustrations appearing in Communications over the past year alone have won top honors in the graphic arts industry_beating out the biggest commercial magazines in the publishing world. Caren, our resident world traveler, has a world of opportunity to explore. Whatever path she chooses, I know she will do so with the same passion and colorful flair we've come to count on and admire.

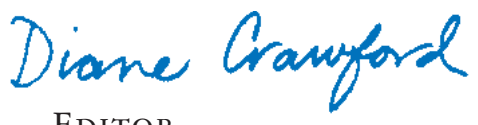

EDITOR
COMMNICATIONS

A monthly publication of the ACM Publications Office

ACM

2 Penn Plaza, Suite 701

New York, NY 10121-0701 USA

(212) 869-7440 FAX: (212) 869-0481

Group Publisher: Scott Delman

Editor: Diane Crawford

Managing Editor: Thomas E. Lambert

Senior Editor: Andrew Rosenbloom

Editorial Assistant: Zarina Strakhan Copyright: Deborah Cotton

\section{Contributing Editors}

Phillip G. Armour; Hal Berghel;

Michael A. Cusumano; Peter J. Denning;

Robert L. Glass; Seymour Goodman;

Rebecca Mercuri; Peter G. Neumann;

Pamela Samuelson; Meg McGinity Shannon

Art Director: Caren Rosenblatt Production Manager: Lynn D’Addesio

Advertising

ACM Advertising Department

2 Penn Plaza, Suite 70I, New York, NY 10I2I-070I

(2I2) 869-7440; Fax: (2I2) 869-048I

\section{Director of Media Sales:}

Jonathan M. Just: jonathan.just@acm.org

For the latest media kit_-including rates-contact:

Graciela Jacome: jacome@acm.org

\section{Contact Points}

CACM editorial: crawford d@acm.org

Copyright permission: permissions@acm.org

Calendar items: calendar@acm.org

Change of address: acmcoa@acm.org

\section{Communications of the ACM}

(ISSN 000I-0782) is published monthly by the ACM, 2 Penn Plaza, Suite 70I, New York, NY I0I2I-070I. Periodicals postage paid at New York, NY I000I, and other mailing offices.

POSTMASTER: Please send address changes to Communications of the ACM, 2 Penn Plaza, Suite 70I, New York, NY I0I21-070I USA

Printed in the U.S.A.

Association for Computing Machinery 


\section{AC The Association for Computing Machinery}

ACM (founded 1947) is an international scientific and educational organization dedicated to advancing the art, science, engineering, and application of information technology, serving both professional and public interests by fostering the open interchange of information and by promoting the highest professional and ethical standards.

\section{Executive Director and CEO: John White Director, ACM U.S. Public \\ Policy Office: Cameron Wilson}

$\begin{array}{ll}\text { Deputy Executive Director and COO: } & \text { Patricia } \\ \begin{array}{ll}\text { Ryan } \\ \text { Director, Office of Information Systems: }\end{array} & \text { Wayne } \\ \begin{array}{l}\text { Graves } \\ \text { Director, Office of Financial Services: }\end{array} & \text { Russell } \\ \text { Harris } & \end{array}$

Financial Operations Planning: Darren Ramdin

Director, Office of Membership: Lillian Israel

Director, Office of Publications: Mark

Mandelbaum

Deputy Director, Magazine

Deputy Director: Bernard Rous Development: Diane Crawford

Publisher, ACM Books and Journals: Jono

Hardjowirogo

Director, Office of SIG Services: Donna Cappo

\begin{tabular}{|c|c|}
\hline $\begin{array}{r}\text { ACM Council } \\
\text { President } \\
\text { Vice-President } \\
\text { Secretary/Treasurer } \\
\text { Past President } \\
\text { Chair, SGB Board } \\
\text {-Chairs, Publications Board }\end{array}$ & $\begin{array}{l}\text { Stuart I. Feldman } \\
\text { Wendy Hall } \\
\text { Alain Chesnais } \\
\text { David A. Patterson } \\
\text { Joseph A. Konstan } \\
\text { Ronald Boisvert, } \\
\text { Holly Rushmeier }\end{array}$ \\
\hline
\end{tabular}

Members-at-Large: Michel Beauduoin-Lafon (2000-2008);

Bruce Maggs (2006-20I0); Barbara Ryder (2000-2008); Kevin

Scott (2006-20I0); Jeannette Wing (2006-20I0); David S. Wise (2004-2008).

SGB Council Representatives:

Norman Jouppi (2006-2007); Robert A. Walker (2006-2008);

Alexander Wolf (2005-2007)
Board Chairs and Standing Committees

Education Board: Andrew McGettrick/Eric Roberts;

SGB Board: Joseph A. Konstan; Membership Services Board:

Terry Coatta; Publications Board: Ronald Boisvert, Holly

Rushmeier

Professions Board: Stephen R. Bourne USACM Committee: Eugene Spafford

\section{SIG Chairs}

SIGACCESS: Vicki Hanson SIGACT: Richard Ladner;

SIGAda: John McCormick; SIGAPL: Guy R. Larocque;

SIGAPP: Barrett Bryant; SIGARCH: Douglas C. Burger;

SIGART: Maria Gini; SIGBED: Lothar Theile;

SIGCAS: Florence Appel; SIGCHI: Julie Jacko;

SIGCOMM: Mark Crovella; SIGCSE: Barbara Boucher Owens;

SIGDA: Diana Marculescu; SIGDOC: Brad Mehlenbacher;

SIGecom: David Pennock SIGEVO: Darrell Whitley;

SIGGRAPH: G. Scott Owen; SIGIR: Elizabeth Liddy;

SIGITE: Han Reichgelt; SIGKDD: Gregory Piatetsky-Shapiro;

SIGMETRICS: Carey Williamson; SIGMICRO: Erik Altman;

SIGMIS: Janice Sipior; SIGMOBILE: David B. Johnson;

SIGMOD: Raghu Ramakrishnan; SIGMULTIMEDIA: Klara

Nahrstedt; SIGOPS: Doug Terry; SIGPLAN: Kathleen Fisher;

SIGSAC: Virgil D. Gligor; SIGSAM: Mark W. Giesbrecht;

SIGSIM: Simon J.E. Taylor; SIGSOFT: William G. Griswold;

SIGUCCS: Leila Lyons; SIGWEB: Ethan Munson

For information from Headquarters: (212) 869-7440

ACM U.S. Public Policy Office:

Cameron Wilson, Director

I 100 Seventeenth St., NW

Suite 507

Washington, DC 20036 USA

$+|-202-659-97|||-o f f i c e$

+I-202-667-1066-fax

wilson_c@acm.org

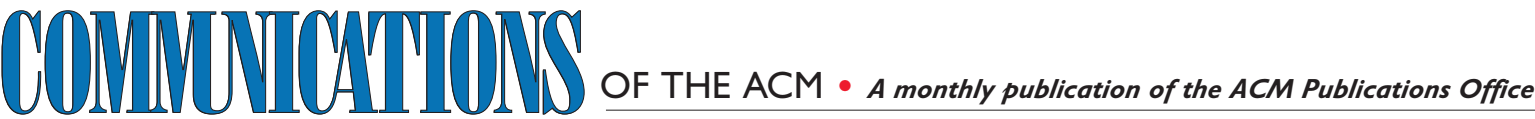

ACM, 2 Penn Plaza, Suite 70I, New York, NY I0I2I-070I USA (2I2) 869-7440 FAX: (2I2) 869-048I

\section{Editorial Advisory Board}

Gordon Bell; Hal Berghel; Grady Booch;

Nathaniel Borenstein; Vinton G. Cerf

Kilnam Chon; Jacques Cohen; Larry L. Constantine;

Jon Crowcroft; Peter J. Denning; Mohamed E. Fayad;

Usama Fayyad; Christopher Fox; Ravi Ganesan;

Don Hardaway; Karen Holtzblatt; Pattie Maes;

Eli Noam; Cherri Pancake; Yakov Rekhter;

Douglas Riecken; Ted Selker; Dennis Tsichritzis;

Ronald Vetter

\section{Publications Board}

Co-Chairs: Ronald F. Boisvert and Holly Rushmeier Board Members: Gul Agha; Michel BeaudouinLafon; Carol Hutchins; Mary Jane Irwin; Ee-ping Lim; Keith Marzullo; M. Tamer Ozsu; Vincent Shen; Mary Lou Soffa; Ricardo Baeza-Yates

\section{ACM Copyright Notice}

Copyright (C) 2008 by Association for Computing Machinery, Inc. (ACM). Permission to make digital or hard copies of part or all of this work for personal or classroom use is granted without fee provided that copies are not made or distributed for profit or commercial advantage and that copies bear this notice and full citation on the first page.
Copyright for components of this work owned by others than ACM must be honored. Abstracting with credit is permitted. To copy otherwise, to republish, to post on servers, or to redistribute to lists, requires prior specific permission and/or fee. Request permission to publish from: Publications Dept. ACM, Inc. Fax + I (2I2) 869-048I or email <permissions@ acm.org>

For other copying of articles that carry a code at the bottom of the first or last page or screen display, copying is permitted provided that the per-copy fee indicated in the code is paid through the Copyright Clearance Center, 222 Rosewood Drive, Danvers, MA 01923, 508-750-8500, 508-750-4470 (fax).

\section{Subscriptions}

Annual subscription cost is included in the society member dues of $\$ 99.00$ (for students, cost is included in $\$ 40.00$ dues); the nonmember annual subscription is $\$ 189.00$ See top line of mailing label for subscription expiration date coded in four digits: the first two are year, last two, month of expiration. Microfilm and microfiche are available from University Microfilms International, 300 North Zeeb Road, Dept. PR, Ann Arbor, MI 48I06; (800) 521-0600.
Single Copies are $\$ 8$ to members and $\$ 17$ to nonmembers. Please send orders prepaid plus $\$ 7$ for shipping and handling to ACM Order Dept., P.O. Box II4 I4, New York, NY 10286-14|4 or call (2I2) 626-0500. For credit card orders call (800) 342-6626. Order personnel on duty 8:30-4:30 EST. After hours, please leave message and order personnel will return your call.

\section{Notice to Past Authors of}

ACM-Published Articles ACM intends to create a complete electronic archive of all articles and/or other material previously published by ACM. If you were previously published by ACM in any journal or conference proceedings prior to 1978, or any SIG newsletter at any time, and you do not want this work to appear in the ACM Digital Library, please inform permissions@acm.org, stating the title of the work, the author(s), and where and when published. 